\title{
Evaluation of microbiological safety in commercial Jeotgal
}

\author{
Sun-A Choi, Seong-Eun An, Hee-Gyeong Jeong, Seo-Hyun Lee, \\ Kwang-Ho Mun, Jung-Beom Kim* \\ Department of Food Science and Technology, Sunchon National University, Sunchon 57922, Korea
}

\section{시중 유통 중인 젓갈의 미생물학적 안전성 평가}

\author{
최선아·안성은 · 정희경 · 이서현 · 문광호·김중범* \\ 순천대학교 식품공학과
}

\begin{abstract}
This study investigated the prevalence of total aerobic bacteria, coliform and food poisoning (Bacillus cereus) bacteria in commercial Jeotgal for the evaluation of microbiological safety. The mean mass of total aerobic bacteria was 4.8 $\pm 1.4 \mathrm{log}$ CFU/g in Jeotgal. Coliform was detected in $17(48.6 \%)$ of 35 seasoned Jeotgal; 14 (42.4\%) of 33 low salted Jeotgal compared with three (16.7\%) of 18 general salted Jeotgal; and in three (37.5\%) of eight HACCP certificated Jeotgal compared with $14(32.6 \%)$ of 43 non-HACCP certificated Jeotgal. Bacillus cereus was detected in two (12.5\%) of 16 non-seasoned Jeotgal compared with 20 (57.1\%) of 35 seasoned Jeotgal; in 19 (57.6\%) of 33 low salted Jeotgal compared with three (16.7\%) of 18 general salted Jeotgal, and in four (50.0\%) of eight HACCP certificated Jeotgal compared with 18 (41.9\%) of 43 non-HACCP certificated Jeotgal. Overall, our results showed that coliform and $B$. cereus contamination was highest in the seasoned and low salted Jeotgal. It is necessary to improve the microbiological safety low salted and seasoned Jeotgal. The HACCP system in Jeotgal is reconfirmed for the enhancement of microbiological safety.
\end{abstract}

Key words : Jeotgal, microbiological safety, package, salt contents, HACCP

\section{서 론}

젓갈은 대한민국을 대표하는 전통수산발효식품으로 어 패류의 근육, 내장 또는 생식소 등에 다량의 식염을 첨가한 후 자가소화 효소 및 미생물의 분해 작용에 의하여 발효, 숙성된 식품이다(1). 식품공전 상 젓갈의 정의는 “어류, 갑 각류, 연체류, 극피류 등에 식염을 가하여 발효 숙성한 것 또는 이를 분리한 여액에 식품 또는 식품첨가물을 가하여 가공한 젓갈, 양념젓갈, 액젓, 조미액젓"을 지칭한다(2). 젓 갈은 소금을 이용함으로서 부패를 막고, 저장성을 가지게 되며 숙성시켜 독특한 향미와 맛을 가지고 있어 한국인이

*Corresponding author. E-mail : okjbkim@sunchon.ac.kr Phone : 82-61-750-3259, Fax : 82-61-750-3208

Received 9 February 2018; Revised 5 March 2018; Accepted 7 March 2018.

Copyright (c) The Korean Society of Food Preservation. All rights reserved.
좋아하는 대표적인 식품이다(3). 우리나라는 삼면이 바다 로 둘러싸여 있고 한류와 난류가 교차하며 수산물의 종류가 매우 다양하여 곡류와 더불어 다양한 수산물을 섭취하여왔 다. 그러나 어패류가 다량 어획되면 일시에 소비하기가 어 려워 소금에 절여 저장하였는데 이것이 점차 젓갈로 발전하 게 되었다(4). 젓갈에 대한 우리나라 최초 문헌은 삼국사기 신라본기에 왕비를 맞이할 때 신문왕이 예물로 쌀·술·장·육 포와 함께 젓갈을 지칭하는 '해'를 왕비에게 결혼 예물로 보낼 정도로 아주 귀한 음식(5)으로 전해지고 있다. 고려시 대에 이르러 젓갈의 종류 및 이용 범위가 넓어졌으며, 향약 구급방에 식해류 사용기록이 전해지고 있다(6). 조선시대 ‘쇄미록'에 식염만을 사용하는 식해류가 기록되어 있고(7) 세종실록지리지에 다양한 젓갈의 종류와 제조법이 전해지 고 있다(6). 또한 가정에서 소규모로 제조되던 젓갈이 현대 에 이르러 대량생산 체제를 갖추는 등 다양한 형태의 젓갈 이 판매되고 있다(6). 젓갈의 제조방법에는 소금에 절이는 염해법, 소금, 술, 기름, 천초를 혼합하여 발효시키는 주국 
어법, 소금과 누룩으로 발효시킨 어장육법, 소금, 엿기름, 찹쌀밥 등을 혼합하여 발효시킨 식해법이 전해 내려오고 있다(8). 현대적 젓갈 제조방법은 어패류에 식염을 가하여 발효시킨 젓갈이 대표적이며 이 젓갈에 고춧가루 등 조미료 를 가한 것을 양념젓갈이라 한다. 또한 젓갈 여과액을 숙성 하여 액젓 또는 조미액젓이라고 한다(1).

젓갈류의 국내 판매액은 2015년 2,990억 원의 매출을 나타내어(9) 특정 지역에서만 소비되는 식품이 아닌 한국인 의 식탁에 빈번하게 오르는 식품이다(10). 옛날에는 장기간 저장하기 위하여 20-25\%의 높은 식염을 첨가하였으나(11) 최근 건강에 대한 관심이 높아지고 식염이 고혈압, 신장병 등 각종 생활 습관 병을 유발하는 것으로 밝혀져 저염젓갈 을 선호하는 추세를 보이고 있다 $(11,12)$. 이러한 저염화는 젓갈에 대한 미생물 오염 예방을 어렵게 할 수 있으며 2015 년 식품의약품안전처 발표 결과 일부 젓갈에서 대장균이 검출되는 등 위생상 문제점이 보고되었다. 따라서 젓갈의 미생물 오염 등 미생물학적 안전성에 대한 연구가 필요하 다. 그러나 현재까지의 연구를 살펴보면 저식염 오징어 젓 갈의 숙성 중 품질변화 및 최적 유통기한 설정(13), 식염농 도 및 숙성 온도가 멸치 젓갈의 숙성 중 위생품질인자의 변화에 미치는 영향(14), 식염 첨가량이 다른 멸치 육젓의 숙성 중 이화학적 특성의 변화(15), 멸치 젓갈의 인공 소화 시 N-Nitrosamine 생성과 돌연변이의 상관성(16), 진주담치 양념젓갈의 이화학적 특성(17), 멸치젓갈 추출물이 돌연변 이 유발에 미치는 영향(18) 등 젓갈의 이화학적 품질특성 및 발효에 관한 연구에 집중 되어 있고, 젓갈의 미생물학적 안전성에 대한 연구는 미약한 실정이다. 따라서 본 연구에 서는 시중 유통 중인 젓갈의 일반세균, 대장균군, 식중독세 균 오염도를 조사하여 미생물학적 안전성을 평가하고자 하였다.

\section{재료 및 방법}

\section{실험재료}

본 실험에 사용한 재료는 2017년 4월부터 6월까지 전라 남도 순천, 여수의 재래시장 및 마트에서 판매중인 젓갈과 인터넷을 통하여 판매중인 젓갈 등 총 51건을 실험대상으 로 하였다(Table 1). 젓갈의 종류는 생산량이 가장 많은 멸치 젓, 새우젓, 명란젓, 오징어젓, 황석어젓 등 14 종류의 젓갈 을 실험대상으로 하였다. 구매한 제품 중 재래시장 및 마트 에서 소분하여 비닐 또는 플라스틱 용기에 담아 판매하는 젓갈이 31 건(60.8\%)이었고, 완제품으로 포장하여 판매하 는 젓갈이 20건(39.2\%)이었다. 젓갈을 식품유형별로 분류 하였을 때 멸치젓, 새우젓 등의 젓갈류 16건(31.4\%), 낙지 젓, 명란젓, 오징어젓 등 양념젓갈이 35건(68.6\%)이었다. $\mathrm{HACCP}$ 인증이 된 젓갈은 8 건(15.7\%), HACCP 인증이 되지
않은 젓갈은 43건(84.3\%)이었다(Table 2).

식 염

식염은 식품공전 회화법(2)에 따라 실험하였다. 검체 1-2 $\mathrm{g}$ 을 취하여 수욕 상에서 증발건조한 후 회화시켜 이를 증류 수에 용해하였다. 다시 증류수를 가하여 $500 \mathrm{~mL}$ 로 한 후 여과하여 여액 $10 \mathrm{~mL}$ 에 크롬산칼륨(DaeJung, Siheung, Korea)시액 2-3방울을 가하고 $0.02 \mathrm{~N}$ 질산은(DaeJung)액으 로 적정하여 식염함량을 산출하였다.

일반세균

일반세균은 식품공전 표준평판법(2)에 따라 실험하였다. 검체 $25 \mathrm{~g}$ 을 멸균 filter bag에 취하여 멸균인산완충희석액 $225 \mathrm{~mL}$ 를 가한 후 stomacher(BagMixer®400, Interscience, St Nom, France)로 60초간 균질화하였다. 균질된 시험 원액 을 10 배 계단 희석하여 각각의 희석액과 원액을 시험용액 으로 하였다. 각각의 시험용액 $1 \mathrm{~mL}$ 를 페트리디쉬에 가한 후, 표준한천배지(Oxoid, London, England) 약 $15 \mathrm{~mL}$ 를 분 주하여 잘 혼합 응고시켰다. 응고된 페트리디쉬를 $35^{\circ} \mathrm{C}$ 에 서 48 시간 배양하여 형성된 집락수를 일반세균수로 계수하 였다.

대장균군

대장균군은 식품공전 데스옥시콜레이트유당한천배지 법(2)에 따라 실험하였다. 일반세균 실험을 위해 준비한 각각의 시험용액 $1 \mathrm{~mL}$ 를 패트리디쉬에 가한 후, Desoxycholate lactose agar(Oxoid, London, England) 약 $15 \mathrm{~mL}$ 를 분주하여 잘 혼합 응고시켰다. 응고된 페트리디쉬는 $35^{\circ} \mathrm{C}$ 에서 24 시 간 배양하여 형성된 붉은색 집락을 대장균군수로 계수하였 다.

\section{식중독세균}

식중독세균은 Multiplex pathogenic detection PCR kit(Kogenebiotech, Seoul, Korea)를 이용하여 Salmonella spp., Listeria monocytogenes, Bacillus cereus, Escherichia coli O157, Yersinia enterocolitica, Vibrio parahaemolyticus, Staphylococcus aureus 등 총 7종의 식중독세균을 실험하였 다. 실험방법은 젓갈 시료 51건을 각각 $25 \mathrm{~g}$ 씩 취한 후 225 $\mathrm{mL}$ Tryptic soy broth(Oxoid, London, England) 배지에 가하 여 $35^{\circ} \mathrm{C}$ 에서 24 시간 배양하였다. 배양액 $1 \mathrm{~mL}$ 를 eppendorf tube에 취하여 12,000 rpm(Smart R17, Hanil scientific, Gimpo, Korea)에서 10 분간 원심분리 하였다. 원심분리 된 eppendorf tube의 상층 액을 제거한 후 멸균증류수 $1 \mathrm{~mL}$ 를 가하여 $12,000 \mathrm{rpm}$ 에서 10 분간 원심분리 하였다. 이 과정을 3 회 반복한 후 eppendorf tube에 멸균증류수 $1 \mathrm{~mL}$ 를 가하여 $99^{\circ} \mathrm{C}$ 히팅블럭(HB-96D, Daihan Scientific, Wonju, Korea)에 서 10 분간 가열하였다. 가열된 eppendorf tube를 $12,000 \mathrm{rpm}$ 
에서 10 분간 원심분리 하여 상층 액을 PCR 주형 $\mathrm{DNA}$ 로 사용하였다. 식중독균의 특이유전자를 확인하기 위하여 $2 \%$ 아가로즈 겔 상에 PCR product $5 \mu \mathrm{L}$ 를 로딩하여 110 $\mathrm{V}$ 에서 30 분간 전기영동을 실시하였다. 전기영동 결과를 식중독세균 특이유전자 증폭 밴드 사이즈와 비교하여 $L$. monocytogenes, B. cereus, E. coli O157, Y. enterocolitica, V. parahaemolyticus, S. aures, Salmonella spp. 유무를 판정 하였다(Table 3).

\section{통계처리}

통계처리는 SPSS V17.0(SPSS Inc, Chicago, IL, USA)을 이용하여 수행하였으며, 독립표본 $\mathrm{T}$-검정으로 두 집단 간 의 평균값을 비교하여, $\mathrm{p}<0.05$ 수준에서 일반세균수와 대장 균군수의 유의적인 차이를 검증하였다.

\section{결과 및 고찰}

\section{젓갈 중 식염함량}

젓갈의 식염함량 분석 결과는 Table 1 에 나타내었다. 식 염함량별로 분류하였을 때 총 51건의 젓갈 중 33 건(64.7\%) 의 젓갈이 식염함량 $10 \%$ 미만인 저염젓갈이었으며 18 건 (35.3\%)의 젓갈이 식염함량 $10 \%$ 이상인 젓갈이었다. 실험 에 사용된 젓갈의 평균 식염함량은 $10.9 \%$ 였으며 새우젓 3 번 검체의 식염함량이 $30.0 \%$ 로 가장 높은 식염함량을 나 타내었으며 가자미식해 1 번 검체의 식염함량이 $4.0 \%$ 로 가 장 낮게 나타났다. 실험대상 젓갈 중 33건(64.7\%)이 저염젓 갈로 분류되었는데 이러한 결과는 식염이 고혈압 등 생활습 관병의 원인으로 보고되는 등 $(1,11)$ 저염식품을 선호하는 경향에 따라 저염젓갈의 생산 및 판매가 기존 식염함량젓갈 에 비해 증가한 결과로 판단된다.

Table 1. Analysis of salt content (\%) in Joetgal

\begin{tabular}{|c|c|c|c|c|c|}
\hline No & Types of Jeotgal & $\begin{array}{l}\text { Salt content } \\
(\%)\end{array}$ & No & Types of Jeotgal & $\begin{array}{l}\text { Salt content } \\
(\%)\end{array}$ \\
\hline 1 & Fermented scallop 1 (Galibi-jeot) & 5.2 & 27 & Salted fermented big eye herring 2 (Baendaeng-i-jeot) & 10.1 \\
\hline 2 & Flatfish sikhae ${ }^{1)} 1$ (Gajamisighae) & 4.0 & 28 & Salted fermented shrimp 1 (Saeu-jeot) & 24.8 \\
\hline 3 & Salted baby octopuses 1 (Kkolttugi-jeot) & 9.6 & 29 & Salted fermented shrimp 2 (Saeu-jeot) & 25.1 \\
\hline 4 & Salted baby octopuses 2 (Kkolttugi-jeot) & 7.6 & 30 & Salted fermented shrimp 3 (Saeu-jeot) & 30.0 \\
\hline 5 & Nagij-jeot' 1 & 7.9 & 31 & Salted fermented shrimp 4 (Saeu-jeot) & 23.0 \\
\hline 6 & Nagji-jeot 2 & 4.2 & 32 & Salted fermented shrimp 5 (Saeu-jeot) & 21.9 \\
\hline 7 & Nagji-jeot 3 & 4.6 & 33 & Salted fermented shrimp 6 (Saeu-jeot) & 19.2 \\
\hline 8 & Nagji-jeot 4 & 8.6 & 34 & Salted fermented shrimp 7 (Saeu-jeot) & 22.5 \\
\hline 9 & Nagji-jeot 5 & 5.4 & 35 & Salted fermented squid 1 (Ojingeo-jeot) & 8.8 \\
\hline 10 & Nagji-jeot 6 & 6.6 & 36 & Salted fermented squid 2 (Ojingeo-jeot) & 8.3 \\
\hline 11 & Nagji-jeot 7 & 6.9 & 37 & Salted fermented squid 3 (Ojingeo-jeot) & 8.0 \\
\hline 12 & Salted anchovy 1 (Myeolchi-jeot) & 13.6 & 38 & Salted fermented squid 4 (Ojingeo-jeot) & 11.2 \\
\hline 13 & Salted anchovy 2 (Myeolchi-jeot) & 17.3 & 39 & Salted fermented squid 5 (Ojingeo-jeot) & 9.4 \\
\hline 14 & Salted anchovy 3 (Myeolchi-jeot) & 7.5 & 40 & Salted fermented squid 6 (Ojingeo-jeot) & 11.7 \\
\hline 15 & Salted anchovy 4 (Myeolchi-jeot) & 14.6 & 41 & Salted fermented squid 7 (Ojingeo-jeot) & 7.0 \\
\hline 16 & Salted fermented Alaska pollack roe 1 (Myeonglan-jeot) & 13.3 & 42 & Salted fermented squid 8 (Ojingeo-jeot) & 5.0 \\
\hline 17 & Salted fermented Alaska pollack roe 2 (Myeonglan-jeot) & 7.2 & 43 & Salted fermented clam 1 (Jogae-jeot) & 12.0 \\
\hline 18 & Salted fermented Alaska pollack roe 3 (Myeonglan-jeot) & 7.9 & 44 & Salted fermented Alaska pollack tripe 1 (Changnan-jeot) & 6.6 \\
\hline 19 & Salted fermented Alaska pollack roe 4 (Myeonglan-jeot) & 6.1 & 45 & Salted fermented Alaska pollack tripe 2 (Changnan-jeot) & 6.8 \\
\hline 20 & Salted fermented Alaska pollack roe 5 (Myeonglan-jeot) & 6.9 & 46 & Salted fermented Alaska pollack tripe 3 (Changnan-jeot) & 8.8 \\
\hline 21 & Salted fermented Alaska pollack roe 6 (Myeonglan-jeot) & 6.4 & 47 & Salted fermented Alaska pollack tripe 4 (Changnan-jeot) & 6.5 \\
\hline 22 & Salted fermented Alaska pollack roe 7 (Myeonglan-jeot) & 5.0 & 48 & Salted fermented Alaska pollack tripe 5 (Changnan-jeot) & 6.5 \\
\hline 23 & Salted fermented Alaska pollack roe 8 (Myeonglan-jeot) & 5.3 & 49 & Salted herring roe 1 (Cheong-eo-jeot) & 7.8 \\
\hline 24 & Salted fermented Alaska pollack roe 9 (Myeonglan-jeot) & 7.1 & 50 & Salted yellow corvina 1 (Hwangseog-eo-jeot) & 20.6 \\
\hline 25 & Myeongtaechomuchimin 1 & 5.5 & 51 & Salted yellow corvina 2 (Hwangseog-eo-jeot) & 28.1 \\
\hline 26 & Salted fermented big eye herring 1 (Baendaeng-i-jeot) & 10.6 & & Mean & 10.9 \\
\hline
\end{tabular}

${ }^{1)}$ Flatfish sikhae (Gajami sighae), steamed food with salt, cooked grains and chili powder.

${ }^{2}$ Nagji-jeot, salt and red pepper paste with small octopus.

${ }^{3)}$ Myeongtaechomuchim, pollack with vinegar dressing. 
Table 2. Classification of packaging type, seasoning type, salt content, and HACCP certification in Jeotgal

\begin{tabular}{|c|c|c|c|c|c|c|c|c|c|}
\hline \multirow[b]{2}{*}{ Food name } & \multirow{2}{*}{$\begin{array}{l}\text { Number of } \\
\text { samples }\end{array}$} & \multicolumn{2}{|c|}{ Packaging type } & \multicolumn{2}{|c|}{ Seasoning type } & \multicolumn{2}{|c|}{ Salt content } & \multicolumn{2}{|c|}{ HACCP } \\
\hline & & Packaged & Unpackaged & Jeotgal & $\begin{array}{c}\text { Seasoned } \\
\text { Jeotgal }\end{array}$ & $\begin{array}{c}\text { Low salt } \\
(<10 \%)\end{array}$ & $\begin{array}{c}\text { General salt } \\
(\geq 10 \%)\end{array}$ & Certification & $\begin{array}{c}\text { Non- } \\
\text { certification }\end{array}$ \\
\hline Fermented scallop (Galibi-jeot) & 1 & 1 & - & - & 1 & 1 & - & - & 1 \\
\hline Flatfish sikhae ${ }^{1)}$ (Gajamisighae) & 1 & 1 & - & 1 & - & 1 & - & - & 1 \\
\hline Salted baby octopuses (Kkolttugi-jeot) & 2 & - & 2 & - & 2 & 2 & - & - & 2 \\
\hline Nagji-jeot ${ }^{2}$ & 7 & 4 & 3 & - & 7 & 7 & - & 2 & 5 \\
\hline Salted anchovy (Myeolchi-jeot) & 4 & 1 & 3 & 4 & - & 1 & 3 & - & 4 \\
\hline Salted fermented Alaska pollack roe (Myeonglan-jeot) & 9 & 3 & 6 & - & 9 & 8 & 1 & 2 & 7 \\
\hline Myeongtaechomuchim ${ }^{3)}$ & 1 & 1 & - & - & 1 & 1 & - & - & 1 \\
\hline Salted fermented big eye herring (Baendaeng-i-jeot) & 2 & - & 2 & 2 & - & - & 2 & - & 2 \\
\hline Salted fermented shrimp (Saeu-jeot) & 7 & 2 & 5 & 7 & - & - & 7 & 1 & 6 \\
\hline Salted fermented squid (Ojingeo-jeot) & 8 & 3 & 5 & - & 8 & 6 & 2 & 1 & 7 \\
\hline Salted fermented clam (Jogae-jeot) & 1 & - & 1 & - & 1 & - & 1 & - & 1 \\
\hline Salted fermented Alaska pollack tripe (Changnan-jeot) & 5 & 3 & 2 & - & 5 & 5 & - & 2 & 3 \\
\hline Salted herring roe (Cheong-eo-al-jeot) & 1 & 1 & - & - & 1 & 1 & - & - & 1 \\
\hline Salted yellow corvina (Hwangseog-eo-jeot) & 2 & - & 2 & 2 & - & - & 2 & - & 2 \\
\hline Total & 51 & 20 & 31 & 16 & 35 & 33 & 18 & 8 & 43 \\
\hline
\end{tabular}

${ }^{15}$ Flatfish sikhae (Gajami sighae), steamed food with salt, cooked grains and chili powder.

${ }^{2)}$ Nagji-jeot, salt and red pepper paste with small octopus.

${ }^{3)}$ Myeongtaechomuchim, pollack with vinegar dressing.

Table 3. PCR product size and target gene

\begin{tabular}{lcc}
\hline \multicolumn{1}{c}{ Pathogen } & Target gene & $\begin{array}{c}\text { Amplicon size } \\
\text { (bp) }\end{array}$ \\
\hline L. monocytogenes & prfA & 450 \\
B. cereus & groEL & 303 \\
E. coli 0157 & $V T 2$ & 208 \\
Y. enterocolitica & inV & 562 \\
V. parahaemolyticus & toxR & 375 \\
S. aures & femA & 264 \\
Salmonella spp. & ipaH & 141 \\
\hline
\end{tabular}

\section{젓갈 중 일반세균 오염현황}

젓갈의 일반세균수 정량시험 결과는 Table 4,5 에 나타내 었다. 일반세균은 51건 모두에서 검출되었고 검출량은 평 균 $4.8 \pm 1.4 \log \mathrm{CFU} / \mathrm{g}$ 으로 나타났다. 조개젓이 평균 5.9 $\log \mathrm{CFU} / \mathrm{g}$ 으로 가장 높은 오염도를 나타내었으며 그 다음 으로 명태 초무침이 평균 $5.7 \log \mathrm{CFU} / \mathrm{g}$, 가리비젓이 평균 $5.6 \log \mathrm{CFU} / \mathrm{g}$ 으로 나타났다. 포장유형에 따른 젓갈의 일반 세균 검출현황은 완제품으로 포장하여 판매되고 있는 경우 평균 $5.0 \pm 0.9 \log \mathrm{CFU} / \mathrm{g}$, 소분 판매되고 있는 경우 평균 $4.7 \pm 1.6 \log \mathrm{CFU} / \mathrm{g}$ 으로 포장 유무와 관계없이 일반세균이 검출되었다. 젓갈과 양념젓갈의 일반세균 검출현황을 살펴 보면 젓갈은 평균 $3.5 \pm 1.1 \log \mathrm{CFU} / \mathrm{g}$, 양념젓갈은 평균
$5.4 \pm 1.1 \log \mathrm{CFU} / \mathrm{g}$ 이 검출되어 양념젓갈이 젓갈에 비해 일 반세균 오염도가 유의적으로 높게 나타났다. 식염함량에 따른 일반세균 검출현황은 저염젓갈이 평균 $5.2 \pm 1.0 \mathrm{log}$ $\mathrm{CFU} / \mathrm{g}$, 기존 식염함량 젓갈이 평균 $4.1 \pm 1.8 \log \mathrm{CFU} / \mathrm{g}$ 으로 저염젓갈의 일반세균 오염도가 유의적으로 높게 나타났다. $\mathrm{HACCP}$ 인증 유무에 따른 일반세균 검출현황을 살펴보면 $\mathrm{HACCP}$ 인증된 8 건에서 평균 $4.8 \pm 1.0 \mathrm{log} \mathrm{CFU} / \mathrm{g}$ 이 검출되 었고, $\mathrm{HACCP}$ 이 인증되지 않은 43건의 젓갈에서 일반세균 은 평균 $4.8 \pm 1.5 \log \mathrm{CFU} / \mathrm{g}$ 으로 검출되어 $\mathrm{HACCP}$ 인증 유무 와 관계없이 일반세균이 검출되었다.

$\mathrm{Ha}$ 등(19)에 따르면 완제품으로 포장하여 판매되는 새우 젓의 경우 일반세균 오염수준이 $2.7 \log \mathrm{CFU} / \mathrm{g}$, 즉석으로 소분 판매되는 새우젓이 $3.6 \log \mathrm{CFU} / \mathrm{g}$ 이었다. 본 실험결과 일반세균 오염수준이 평균 $4.8 \log \mathrm{CFU} / \mathrm{g}$ 으로 $\mathrm{Ha}$ 등의 보고 에 비해 높게 나타났고 포장판매 중인 젓갈의 일반세균 오염도가 더 높아 포장 판매되는 젓갈의 미생물학적 안전 조치가 필요한 것으로 판단된다. Lee 등(20)의 연구결과에 따르면 젓갈류 중 일반세균수는 $3.5 \log \mathrm{CFU} / \mathrm{g}$, 양념젓갈류 중 일반세균수는 $5.5 \log \mathrm{CFU} / \mathrm{g}$ 을 나타내어 본 실험결과와 유사하게 양념젓갈류의 일반세균수 오염도가 높게 나타났 다. 또한 본 실험결과 젓갈의 식염함량이 증가함에 따라 일반세균수가 다소 감소하는 결과를 나타내었다. 이러한 결과는 젓갈의 식염 함량이 높을수록 미생물의 생육이 억제 된다는 Hong 등(21)의 보고와 젓갈의 염도가 증가함에 따라 
Table 4. Detection of total aerobic bacteria in Jeotgal

\begin{tabular}{|c|c|c|c|c|}
\hline Types of Jeotgal & $\begin{array}{l}\text { Number of } \\
\text { samples }\end{array}$ & $\begin{array}{l}\text { Number of detection } \\
\text { samples }\end{array}$ & $\begin{array}{l}\text { Detection } \\
\text { rate }(\%)\end{array}$ & $\begin{array}{l}\text { Mean } \pm \text { STD } \\
(\log \text { CFU/g) }\end{array}$ \\
\hline Fermented scallop (Galibi-jeot) & 1 & 1 & 100 & 5.6 \\
\hline Flatfish sikhae ${ }^{1)}$ (Gajamisighae) & 1 & 1 & 100 & 5.0 \\
\hline Salted baby octopuses (Kkolttugi-jeot) & 2 & 2 & 100 & 5.3 \\
\hline Nagji-jeot ${ }^{2}$ & 7 & 7 & 100 & 5.5 \\
\hline Salted anchovy (Myeolchi-jeot) & 4 & 4 & 100 & 2.9 \\
\hline Salted fermented Alaska pollack roe (Myeonglan-jeot) & 9 & 9 & 100 & 5.4 \\
\hline Myeongtaechomuchim ${ }^{3}$ & 1 & 1 & 100 & 5.7 \\
\hline Salted fermented big eye herring (Baendaeng-i-jeot) & 2 & 2 & 100 & 4.9 \\
\hline Salted fermented shrimp (Saeu-jeot) & 7 & 7 & 100 & 3.3 \\
\hline Salted fermented squid (Ojingeo-jeot) & 8 & 8 & 100 & 5.3 \\
\hline Salted fermented clam (Jogae-jeot) & 1 & 1 & 100 & 5.9 \\
\hline Salted fermented Alaska pollack tripe (Changnan-jeot) & 5 & 5 & 100 & 5.5 \\
\hline Salted herring roe (Cheong-eo-jeot) & 1 & 1 & 100 & 5.0 \\
\hline Salted yellow corvina (Hwangseog-eo-jeot) & 2 & 2 & 100 & 3.0 \\
\hline Total & 51 & 51 & 100 & $4.8 \pm 1.4$ \\
\hline
\end{tabular}

${ }^{1)}$ Flatish sikhae (Gajami sighae), steamed food with salt, cooked grains and chili powder.

${ }^{2}$ Nagji-jeot, salt and red pepper paste with small octopus.

${ }^{3)}$ Myeongtaechomuchim, pollack with vinegar dressing.

${ }^{4} \mathrm{ND}$, not detected.

Table 5. Detection of total aerobic bacteria in Jeotgal according to the types

\begin{tabular}{clcccc}
\hline & Type & $\begin{array}{c}\text { Number of } \\
\text { samples }\end{array}$ & $\begin{array}{c}\text { Number of detection } \\
\text { samples }\end{array}$ & $\begin{array}{c}\text { Detection rate } \\
(\%)\end{array}$ & $\begin{array}{c}\text { Mean } \pm \text { STD } \\
(\log \text { CFU/g) }\end{array}$ \\
\hline \multirow{2}{*}{ Packaging type } & Packaged & 20 & 20 & 100 & $5.0 \pm 0.9^{\mathrm{al})}$ \\
& Unpackaged & 31 & 31 & 100 & $4.7 \pm 1.6^{\mathrm{a}}$ \\
\hline \multirow{2}{*}{ Seasoning type } & Jeotgal & 16 & 16 & 100 & $3.5 \pm 1.1^{\mathrm{c}}$ \\
& Seasoned Jeotgal & 35 & 35 & 100 & $5.4 \pm 1.1^{\mathrm{d}}$ \\
\hline \multirow{2}{*}{ Salt content } & Low salt $(<10 \%)$ & 33 & 33 & 100 & $5.2 \pm 1.0^{\mathrm{e}}$ \\
& General salt $(\geq 10 \%)$ & 18 & 18 & 100 & $4.1 \pm 1.8^{\mathrm{f}}$ \\
\hline \multirow{2}{*}{ HACCP } & HACCP & 8 & 8 & 100 & $4.8 \pm 1.0^{\mathrm{g}}$ \\
\hline & Non-HACCP & 43 & 43 & 100 & $4.8 \pm 1.5^{\mathrm{g}}$ \\
\hline
\end{tabular}

${ }^{1)}$ Different superscripts are significantly different at $p<0.05$.

일반세균수가 감소한다는 Lee 등(20)의 보고와 일치하는 결과였다. 실험결과 젓갈의 제조, 판매 시 온도관리와 젓갈 포장용기의 위생상태 확보가 필요한 것으로 판단되었다. 적은 수의 젓갈을 실험대상으로 하였지만 본 실험결과 $\mathrm{HACCP}$ 인증 유무와 상관없이 일반세균수가 검출되어 $\mathrm{HACCP}$ 인증 제품에 대한 미생물학적 안전 조치가 필요한 것으로 판단된다.

\section{젓갈 중 대장균군 오염현황}

젓갈의 대장균군 실험결과는 Table 6,7 에 나타내었으며
51 건의 젓갈 중 17 건에서 대장균군이 검출되어 $33.3 \%$ 의 검출률을 나타내었다. 평균 검출량은 $0.8 \pm 1.2 \log \mathrm{CFU} / \mathrm{g}$ 으 로 나타났으며 꼴뚜기젓, 오징어젓, 청어알젓이 각각 평균 2.7, 2.1, $2.1 \log \mathrm{CFU} / \mathrm{g}$ 으로 가장 높은 오염도를 나타내었다. 포장유형에 따른 젓갈의 대장균군 검출현황을 살펴보면 완제품으로 포장하여 판매되고 있는 젓갈 20건 중 7 건 (35.0\%)에서 검출되었고, 소분 판매되고 있는 젓갈 31 건 중 10 건(32.6\%)에서 검출되어 포장유무에 관계없이 대장균 군이 검출되었다. 젓갈과 양념젓갈의 대장균군 검출현황을 살펴보면 젓갈 16 건은 대장균군이 검출되지 않았으나 양념 
Table 6. Detection of coliform groups in Jeotgal

\begin{tabular}{|c|c|c|c|c|}
\hline Types of Jeotgal & $\begin{array}{l}\text { Number of } \\
\text { samples }\end{array}$ & $\begin{array}{l}\text { Number of detection } \\
\text { samples }\end{array}$ & $\begin{array}{l}\text { Detection rate } \\
(\%)\end{array}$ & $\begin{array}{l}\text { Mean } \pm \text { STD } \\
(\log \text { CFU/g) }\end{array}$ \\
\hline Fermented scallop (Galibi-jeot) & 1 & $\mathrm{ND}^{4)}$ & - & - \\
\hline Flatfish sikhae ${ }^{1)}$ (Gajamisighae) & 1 & ND & - & - \\
\hline Salted baby octopuses (Kkolttugi-jeot) & 2 & 2 & 100 & 2.7 \\
\hline Nagii-jeot') & 7 & 2 & 28.6 & 1.3 \\
\hline Salted anchovy (Myeolchi-jeot) & 4 & $\mathrm{ND}$ & - & - \\
\hline Salted fermented Alaska pollack roe (Myeonglan-jeot) & 9 & 5 & 55.6 & 1.5 \\
\hline Myeongtaechomuchim $\left.{ }^{3}\right)$ & 1 & $\mathrm{ND}$ & - & - \\
\hline Salted fermented big eye herring (Baendaeng-i-jeot) & 2 & ND & - & - \\
\hline Salted fermented shrimp (Saeu-jeot) & 7 & ND & - & - \\
\hline Salted fermented squid (Ojingeo-jeot) & 8 & 6 & 75.0 & 2.1 \\
\hline Salted fermented clam (Jogae-jeot) & 1 & 1 & 100 & 1.00 \\
\hline Salted fermented Alaska pollack tripe (Changnan-jeot) & 5 & ND & - & - \\
\hline Salted herring roe (Cheong-eo-ar-jeot) & 1 & 1 & 100 & 2.1 \\
\hline Salted yellow corvina (Hwangseog-eo-jeot) & 2 & ND & - & - \\
\hline Total & 51 & 17 & 33.3 & $0.8 \pm 1.2$ \\
\hline
\end{tabular}

${ }^{1)}$ Flatfish sikhae (Gajami sighae), steamed food with salt, cooked grains and chili powder.

${ }^{2)}$ Nagji-jeot, salt and red pepper paste with small octopus.

${ }^{3)}$ Myeongtaechomuchim, pollack with vinegar dressing.

${ }^{4} \mathrm{ND}$, not detected.

Table 7. Detection of coliform groups in Jeotgal according to the types

\begin{tabular}{|c|c|c|c|c|c|}
\hline & Type & $\begin{array}{l}\text { Number of } \\
\text { samples }\end{array}$ & $\begin{array}{c}\text { Number of detection } \\
\text { samples }\end{array}$ & $\begin{array}{l}\text { Detection rate } \\
(\%)\end{array}$ & $\begin{array}{l}\text { Mean } \pm \text { STD } \\
(\log \text { CFU/g) }\end{array}$ \\
\hline \multirow{2}{*}{ Packaging type } & Packaged & 20 & 7 & 35.0 & $0.9 \pm 1.3^{32)}$ \\
\hline & Unpackaged & 31 & 10 & 32.6 & $0.7 \pm 1.1^{\mathrm{a}}$ \\
\hline \multirow{2}{*}{$\begin{array}{l}\text { Seasoning } \\
\text { type }\end{array}$} & Jeotgal & 16 & $\mathrm{ND}^{1)}$ & - & - \\
\hline & Seasoned Jeotgal & 35 & 17 & 48.6 & $1.1 \pm 1.2^{\mathrm{d}}$ \\
\hline \multirow{2}{*}{ Salt content } & Low salt $(<10 \%)$ & 33 & 14 & 42.4 & $1.0 \pm 1.3^{\mathrm{e}}$ \\
\hline & General salt $(\geq 10 \%)$ & 18 & 3 & 16.7 & $0.3 \pm 0.7^{f}$ \\
\hline \multirow{3}{*}{$\begin{array}{l}\text { HACCP } \\
\text { certification }\end{array}$} & HACCP & 8 & 3 & 37.5 & $1.0 \pm 1.5^{\mathrm{g}}$ \\
\hline & Non-HACCP & 43 & 14 & 32.6 & $0.7 \pm 1.1^{\mathrm{g}}$ \\
\hline & Total & 51 & 17 & 33.3 & $0.8 \pm 1.2$ \\
\hline
\end{tabular}

${ }^{1)} \mathrm{ND}$, not detected.

${ }^{2)}$ Different superscripts are significantly different at $\mathrm{p}<0.05$

젓갈 35 건 중 17 건(48.6\%)에서 대장균군이 검출되었다. 또 한 젓갈보다 양념젓갈의 대장균군 오염도도 유의적으로 더 높게 나타났다. 식염 함량에 따른 대장균군의 검출현황 을 살펴보면 저염젓갈 33 건 중 14 건(42.4\%)에서 대장균군 이 검출되었으나 기존 식염함량 젓갈의 경우 18 건 중 3 건 $(16.7 \%)$ 에서 대장균군이 검출되었다. 또한 저염젓갈의 대 장균군 오염도도 유의적으로 더 높게 나타났다. HACCP 인증 유무에 따른 대장균군의 검출현황은 $\mathrm{HACCP}$ 인증된 8 건 중 3 건(37.5\%), $\mathrm{HACCP}$ 이 인증 되지 않은 43 건 중에서
는 14 건(32.6\%)의 젓갈에서 대장균군이 검출되어 $\mathrm{HACCP}$ 인증 유무와 관계없이 대장균군이 검출되었다.

젓갈의 식품공전 미생물규격은 대장균, 대장균군이 설정 되어있고 공통규격에 B. cereus, Clostridium perfringens가 설정 되어 있으나 본 실험에서는 젓갈의 위생 상태를 파악 하고자 위생지표 미생물인 대장균군과 일반세균수를 실험 하였고 젓갈의 호기적 유통환경을 반영하여 B. cereus을 실험하였다. $\mathrm{Ha}$ 등(19)에 따르면 본 연구결과와 상이하게 완제품보다 소분 판매 중인 젓갈의 대장균군 오염빈도가 
더 높게 나타났다고 보고하였다. 이러한 결과는 소분 판매 되는 젓갈의 경우 저염젓갈이 $52 \%$, 완제품으로 포장하여 판매되는 젓갈의 경우 저염젓갈이 $85 \%$ 로 완제품으로 포장 하여 판매되는 젓갈의 저염젓갈 비율이 높아 소분 판매되는 젓갈에 비해 완제품으로 포장된 젓갈의 대장균군 검출률이 높게 나타난 것으로 판단된다. 또한 저염젓갈의 생산과 판 매가 증가함에 따라 소분 판매되는 젓갈의 경우에도 저염젓 갈이 증가할 것으로 예측되어 완제품과 더불어 소분 판매되 는 젓갈도 철저한 위생 관리가 필요할 것으로 판단된다 $(19,20,22)$. Lee 등 $(20)$ 의 연구결과에 따르면 젓갈 $5.9 \%$ 에서 대장균군이 검출된 반면, 양념젓갈 $37.7 \%$ 에서 대장균군이 검출되는 등 본 연구결과와 유사하게 양념젓갈의 대장균군 검출률이 매우 높게 나타났다. 본 실험결과 저염젓갈의 대 장균군 오염빈도가 $42.4 \%$, 기존 식염함량 젓갈의 대장균군 오염빈도가 $16.7 \%$ 로 저염젓갈의 대장균군 오염빈도가 높 게 나타났다. 이러한 결과는 식염농도별 오염도 분석결과 식염함량 $20 \%$ 이상인 젓갈에서 대장균군 오염빈도가 가장 낮게 나타났다는 Lee등(20)의 보고와 일치하는 결과이었 다. 따라서 고혈압 등 생활습관병 예방을 위해 제조, 판매되 고 있는 저염젓갈의 미생물학적 안전성 확보가 필요한 것으
로 판단된다. 또한 실험대상 젓갈의 수가 적지만 본 실험결 과 $\mathrm{HACCP}$ 인증 된 젓갈에서도 대장균군이 검출되어 젓갈 류에 대한 HACCP system 관리가 강화되어야 할 것으로 판단된다.

\section{젓갈 중 식중독세균 오염현황}

젓갈의 식중독세균 실험결과는 Table 8과 Fig. 1에 나타 내었으며 51건의 젓갈 중 22건(43.1\%; 2-4, 14-18, 23, 36-39, $41,44-51$ 번 시료)에서 B. cereus 가 검출되었고 L monocytogenes, E. coli O157, Y. enterocolitica, V. parahaemolyticus, $S$. aures, Salmonella spp. 등 식중독 세균은 검출되지 않았다. 완제품 으로 포장하여 판매되는 20 건의 젓갈 중 12 건(60.0\%)에서 B. cereus 가 검출되었고, 소분 판매되고 있는 31 건 중 10 건 (32.3\%)의 젓갈에서 B. cereus가 검출되었다. 양념젓갈 35 건 중 20 건(57.1\%), 젓갈 16 건 중 2 건(12.5\%)에서 B. cereus 가 검출되었고 저염젓갈은 33 건 중 19 건(57.6\%), 기존 식염 함량 젓갈은 18 건 중 3 건(16.7\%)에서 B. cereus가 검출되었 다. HACCP 인증된 8건 중 4건(50.0\%)에서 B. cereus 가 검출 되었고, $\mathrm{HACCP}$ 이 인증되지 않은 43 건 중 18 건(41.9\%)에서 B. cereus 가 검출되어 HACCP 인증 유무와 상관없이 $B$.

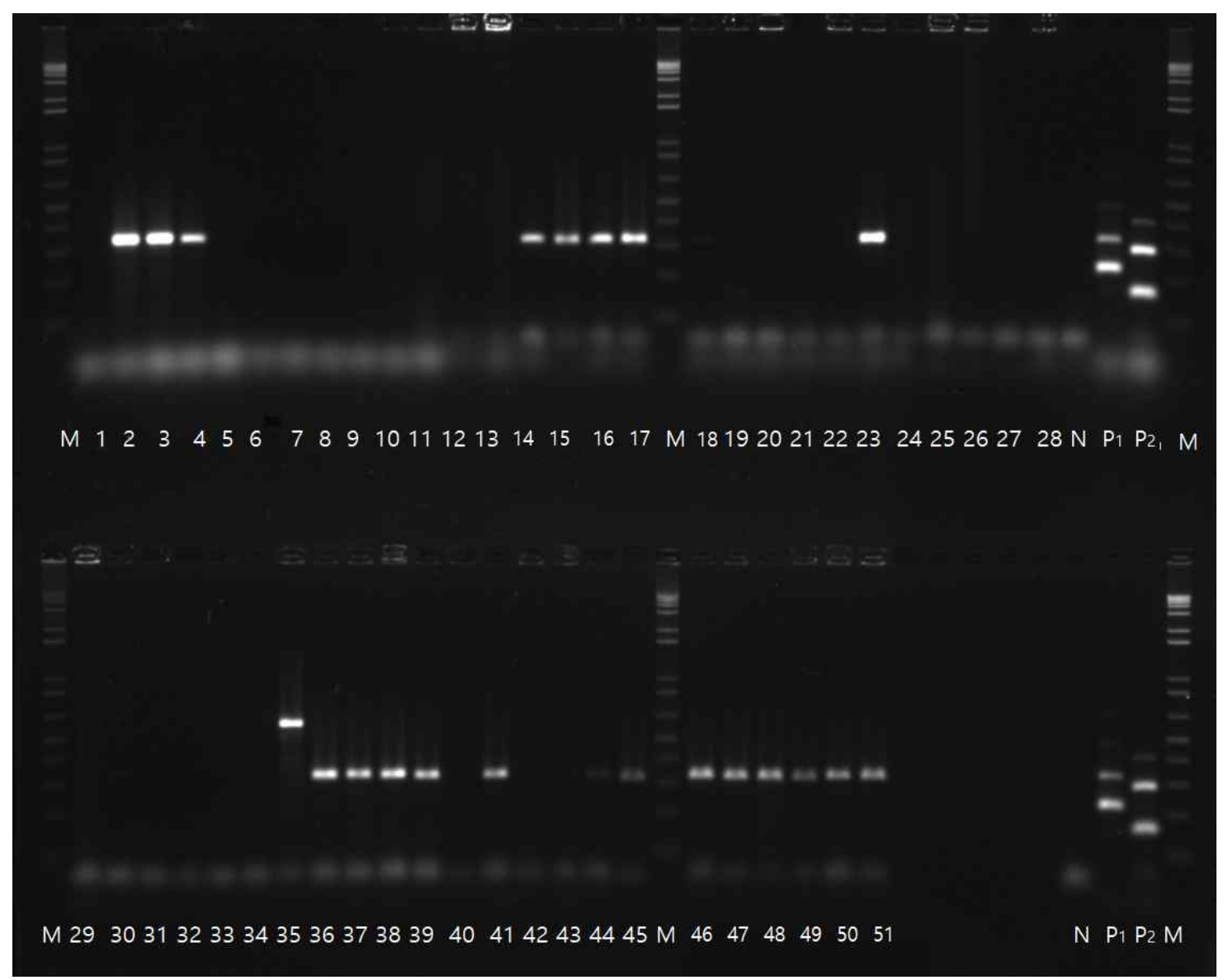

Fig. 1. Gel electrophoresis result of food poisoning bacteria in Jeotgal.

M, size marker; 1-51, sample of Jeotgal, N, negative control; P, positive control. 
cereus가 검출되었다.

젓갈 중 미생물 오염에 관한 연구결과 Bacillus, Micrococcus 속이 빈번히 검출되었고 가리비젓, 가자미식해, 꼴뚜기젓, 멸치젓 등 17 종의 젓갈에서 70 종의 Bacillus 속 균주와 5종 의 Pseudomonas 속 균주가 분리 보고되었다(23-26). 그러나 식중독세균인 B. cereus에 대한보고는 미약하여 51건의 젓 갈 중 22 건(43.1\%)에서 B. cereus 가 검출된 본 연구의 결과 와 직접적인 비교는 곤란하였다. B cereus가 검출된 22 건의 젓갈 중 가자미식해 1 건, 새우젓 1 건으로 총 2 건을 제외한 20건의 젓갈 모두 고춧가루나 양파 등이 첨가된 양념젓갈 로 나타났다. 따라서 양념젓갈에 들어가는 부재료가 젓갈 중 B cereus 주요 오염원으로 판단되며 젓갈 제조 시 사용되 는 부재료의 철저한 위생관리가 필요한 것으로 판단된다. 식염함량에 따른 B. cereus 오염도는 저염젓갈이 기존 식염 함량 젓갈에 비해 높게 나타나 식염함량이 높을수록 $B$. cereus 생육이 억제되는 것으로 판단된다. 따라서 자연계에 널리 분포하고 있는 $B$ cereus의 오염을 예방하기 위해 젓갈 의 철저한 위생관리가 필요한 것으로 판단되며 특히 저염젓 갈, 양념젓갈의 철저한 위생관리가 필요한 것으로 판단되 었다.

양념젓갈과 저염젓갈에서 대장균군 및 B. cereus 오염도 가 높게 나타나 양념젓갈 제조 시 고춧가루 등 부재료의 철저한 위생관리가 필요하며 저염젓갈의 제조, 판매 시 위 생관리에 유의하고, 작업환경 및 작업자의 개인위생확보가 필요한 것으로 판단되었다. 또한 적은 수의 젓갈을 실험대 상으로 하였지만 $\mathrm{HACCP}$ 인증 유무와 관계없이 실험에 사용한 젓갈에서 대장균군 및 B. cereus가 검출되어 젓갈에 대한 $\mathrm{HACCP}$ system 관리가 강화되어야 할 것으로 판단된 다.

Table 8. Detection rate of Bacillus cereus in Jeotgal according to the types

\begin{tabular}{|c|c|c|c|c|}
\hline & Type & $\begin{array}{c}\text { Number of } \\
\text { samples }\end{array}$ & $\begin{array}{c}\text { Number of } \\
\text { detection samples }\end{array}$ & $\begin{array}{c}\text { Detection rate } \\
(\%)\end{array}$ \\
\hline \multirow{2}{*}{$\begin{array}{l}\text { Packaging } \\
\text { type }\end{array}$} & Packaged & 20 & 12 & 60.0 \\
\hline & Unpackaged & 31 & 10 & 32.3 \\
\hline \multirow{2}{*}{$\begin{array}{l}\text { Seasoning } \\
\text { type }\end{array}$} & Jeotgal & 16 & 2 & 12.5 \\
\hline & Seasoned Jeotgal & 35 & 20 & 57.1 \\
\hline \multirow{2}{*}{ Salt content } & Low salt $(<10 \%)$ & 33 & 19 & 57.6 \\
\hline & General salt $(\geq 10 \%)$ & 18 & 3 & 16.7 \\
\hline \multirow{3}{*}{$\begin{array}{l}\text { HACCP } \\
\text { certification }\end{array}$} & HACCP & 8 & 4 & 50.0 \\
\hline & Non-HACCP & 43 & 18 & 41.9 \\
\hline & Total & 51 & 22 & 43.1 \\
\hline
\end{tabular}

\section{요 약}

본 연구에서는 시중 유통 중인 젓갈의 일반세균, 대장균
군, 식중독세균을 분석함으로써 미생물학적 안전성을 평가 하고자 하였다. 본 실험에 사용한 재료는 재래시장 및 마트 에서 판매중인 젓갈과 인터넷을 통하여 판매중인 젓갈 등 총 51건을 실험대상으로 하였다. 일반세균 및 대장균군 실 험은 식품공전에 따랐으며, 식중독세균은 Multiplex pathogenic detection PCR kit를 이용하여 실험하였다. 일반 세균수는 평균 4.8 $\pm 1.4 \log \mathrm{CFU} / \mathrm{g}$ 으로 51건 젓갈 모두에서 검출되었다. 대장균군의 경우 양념젓갈 35 건 중 17 건 (48.6\%)에서 검출되었으나 젓갈 16 건에서는 모두 불검출 되었다. 저염젓갈의 경우 33 건 중 14 건(42.4\%), 기존 식염함 량 젓갈 18 건 중 3 건(16.7\%)에서 검출되었다. HACCP 인증 유무에 따른 대장균군 검출 현황은 $\mathrm{HACCP}$ 인증 8건 중 3 건(37.5\%), $\mathrm{HACCP}$ 미인증 43건 중 14 건(32.6\%)에서 검출 되었다. 식중독세균의 경우 양념젓갈 35 건 중 20 건(57.1\%), 젓갈 16 건 중 2 건(12.5\%)에서 B. cereus가 검출되었고, 저염 젓갈 33 건 중 19 건(57.6\%), 기존 식염함량 젓갈 18 건 중 3 건(16.7\%)에서 B. cereus가 검출되었다. 또한 $\mathrm{HACCP}$ 인증 된 8건 중 4건(50.0\%), $\mathrm{HACCP}$ 미인증 43건 중 18건(41.9\%) 에서 B. cereus가 검출되었다. 본 실험결과 젓갈보다 저염젓 갈에서 대장균군 및 B. cereus 오염도가 높게 나타나 저염젓 갈의 제조, 판매 시 위생관리 및 작업환경관리가 필요하며, 양념젓갈에 추가되는 부재료의 위생관리가 필요한 것으로 판단되었다. 또한 $\mathrm{HACCP}$ 인증 유무와 상관없이 대장균군 및 B. cereus가 검출되어 젓갈에 대한 $\mathrm{HACCP}$ system 관리 가 강화되어야 될 것으로 판단된다.

\section{References}

1. Ha SD, Kim AJ (2005) Technological trends in safety of Jeotgal. Food Sci Ind, 38, 46-64

2. Ministry of Food and Drug Safety. http://www.foodsafetykorea.go.kr/portal/safefoodlife/foo d/foodRvlv/foodRvlv.do\# (accessed August 2017)

3. Oh SC, Cho JS, Nam HY (2000) Changes of the volatile basic nitrogen and free amino acids according to the fermentation of low salt fermented squid. Korean J Soc Food Cookery Sci, 16, 173-181

4. Song KE (2009) The changes of the spatial characteristics in production of salted seafood. Geogr J Korea, 43, 159-172

5. Kim HY (2016) Research on the ritualistic nature of royal wedding food during the Joseon (Choson) dynasty. J Women and history, 25, 29-52

6. Hur SH (1996) Critical review on the microbiological standardization of salt-fermented fish product. J Korean Soc Food Sci Nutr, 25, 885-891 
7. Cha GH (2007) The consumption patterns of animal foods in the sixteenth century as observed through Shamirok Korean J Food Cookery Sci, 23, 703-719

8. An DH, Lee JH (2011) Isolation of bacteria from Jeotgal using high-salt-content media and their growths in high-salt condition. Korean J Microbiol Biotechnol, 39, 294-300

9. Korea Food and Drug Administration (2015) 2015 Production of food and food additives, Ministry of Food and Drug Safety, Seoul, Korea, p 25

10. Moon GS, Song YS, Ryu BM, Jeon YS (1997) The study on the qualities of commercial anchovy sauces and Kimchies prepared with different anchovy sauces. Korean J Soc Food Sci, 13, 272-277

11. Kim BN, Jung SME, Choe JH, Liu XD, Jo CR (2008) Microbiological and sensory characteristics of electron beam irradiated squid Jeotkal and its ingredients. Korean J Agric Sci, 35, 155-165

12. Kim BN, Jang AR, Song HP, Kim YJ, KO BH, JO C (2008) Microbiological quality of Myungran Jeotkal and its ingredients and improvement of shelf-stability by gamma irradiation. Korean J Food Preserv, 15, 606-611

13. Lee KG, Kim SM (2012) Quality changes in low-salted squid Jeotgal during fermentation and determination of shelf-life. J Korean Soc Food Sci Nutr, 41, 687-694

14. Ko YA, Kim SH, Song HS (2017) Effect of salt concentration and fermentation temperature on changes in quality index of salted and fermented anchovy during fermentation. J Food Hyg Saf, 32, 27-34

15. Lee JD, Kang KH, Kwon SJ, Yoon MJ, Park SY, Park JH, Kim JG (2015) Changes of physicochemical properties of salted-fermented anchovy meat Engraulis japonica with different salt content during fermentation at $15^{\circ} \mathrm{C}$. JFMSE, 27, 1457-1469

16. Shon MY, Park HJ, Shin JH, Sung MJ (2004) Correlation of $\mathrm{N}$-nitrosamine formation and mutagenicity in fermented anchovy under simulated gastric digestion. J Korea Soc Food Sci Nutr, 33, 1560-1565
17. Park JS (2011) Physicochemical properties of saltfermented mytilus edulis added with various seasoning sauces. Korean J Food Preserv, 18, 335-340

18. Jung KO, Kang KS, Park KY (2000) Effect of fermented anchovy extracts on the N-methyl-N'-nitro-N-nitrosoguanidineInduced mutagenicities. Korean J Food Sci Technol, 32, 1426-1432

19. Ha JH, Moon ES, Ha SD (2007) Assessment of microbial contamination and safety of commercial shrimp Jeotgal (salt fermented shrimp). J Food Hyg Safe, 22, 105-109

20. Lee SM, Lim JM, Kim KH, Cho SY, Park KS, Sin YM, Cheung CY, Cho JI, You HJ, Kim KH, Cho DH, Lim CJ, Kim OH (2008) Microbiological study using monitoring of microorganism in salt-fermented fishery products. J Food Hyg Safe, 23, 198-205

21. Hong Y, Kim JH, Ahn BH, Cha SK (2000) The effects of low temperature storage and aging of jeot-kal on the microbial counts and microflora. Korean J Food Sci Technol, 32, 1341-1349

22. Lee WD (2001) Recent development of Jeotagal (traditional Korean fermented seafood) and its future. Food Ind Nutr, 6, 23-27

23. Lee KH (1969) Microbiological and enzymological studies on the flavor components of sea food pickles. J Korean Soc Agric Chem Biotechnol, 11, 1-6

24. Cha YJ, Cho SY, Oh KS, Lee EH (1983) Studies on the processing of low salt fermented sea foods: 2 . The taste compounds of low salt fermented sardine. Bull Korean Fish Soc, 16, 140-146

25. Kim MS, Park EJ, Jung MJ, Roh SW, Bae JW (2009) Analysis of prokaryote communities in Korean traditional fermented food, Jeotgal, using culture-dependent method and isolation of a novel strain. Korean J Microbiol, 45, 26-31

26. Kim HR, Han SH, Lee BNR, Jeong DW, Lee JH (2013) Analysis of the bacterial community in Ojingeo-jeotgal and selection of Bacillus species inhibiting the growth of food pathogens. Korean J Microbiol Biotechnol, 41, $462-468$ 